\begin{tabular}{c}
\hline \hline Juntendo \\
Research Profiles \\
\hline \hline Juntendo Medical Journal \\
2015. 61 (2), 184-185
\end{tabular}

\title{
Department of Neurosurgery
}

\section{Principal Investigator: Hajime Arai (Professor)}

We carry out more than 700 surgeries annually, covered all fields of neurosurgery. Our department has developed a strong commitment to update our knowledge on surgical treatment, emergency care, neurology, peri-surgical management, imaging diagnosis, and basic research, in order to provide contemporary education and foster specialists in neurosurgery.

\section{Group Leaders and Research Topics}

1) Masakazu Miyajima (Senior Associate Professor) Kazuaki Shimoji (Associate Professor)

Madoka Nakajima (Associate Professor)

In our group, we are focusing on idiopathic normalpressure hydrocephalus and congenital malformations such as congenital hydrocephalus, craniosynostosis, and spina bifida. Our goal is to find a new way to diagnose these diseases and to develop a new treatment by using samples such as cerebrospinal fluid and blood plasma of these patients.

Hydrocephalus

We are interested in biomarkers such as glycoproteins and microRNA in idiopathic normal-pressure hydrocephalus to explore new diagnostic tools. We are making efforts to identify a target gene for familial hydrocephalus. We also use $\mathrm{H}-\mathrm{Tx}$ rats as a hydrocephalus model to investigate the pathogenesis of hydrocephalus.

\section{Craniosynostosis}

In craniosynostosis, a clinical trial is currently ongoing for the treatment for mild metopic suture synostosis with clinical symptoms. We are also attempting to find target genes for both syndromic and non-syndromic craniosynostosis.

Other congenital malformations

We are also focused on finding target genes for familial cavernous angiomas, Sturge-Weber syndrome, and spina bifida.

Publications:

1) Miyajima M, Nakajima M, Ogino I, Miyata H, Motoi Y, Arai $\mathrm{H}$ : Soluble amyloid precursor protein $\alpha$ in the cerebrospinal fluid as a diagnostic and prognostic biomarker for idiopathic normal pressure hydrocephalus. Eur J Neurol, 2013; 20: 236-242.

2) Watanabe M, Miyajima M, Ogino I, Nakajima M, Arai H: Cerebellar Purkinje Cells Exhibit Increased Expression of HMGB-1 and Apoptosis in Congenital Hydrocephalic H-Tx Rats. Neurosurgery, 2013; 72: 459-467.

3) Miyajima M, Nakajima M, Motoi Y, Moriya M, Sugano H, Ogino I, Nakamura E, Tada N, Kunichika M, Arai H: Leucine-rich $\alpha 2$-glycoprotein is a novel biomarker of neurodegenerative disease in human cerebrospinal fluid and causes neurodegeneration in mouse cerebral cortex. PLoS One, 2013; 8: e74453.

4) Shimoji K, Kimura T, Kondo A, Tange Y, Miyajima M, Arai H: Genetic studies of myelomeningocele. Childs Nerv Syst, 2013; 29: 1417-1425.

5) Nakajima M, Miyajima M, Ogino I, Sugano H, Akiba C, Domon N, Karagiozov KL, Arai H: Use of External Lumbar Cerebrospinal Fluid Drainage and Lumboperitoneal Shunts with Strata NSC Valves in Idiopathic Normal Pressure Hydrocephalus: A Single-Center Experience. World Neurosurg, 2015; 83: 387-393.

6) Okumura A, Yamamoto T, Miyajima M, Shimojima K, Kondo S, Abe S, Ikeno M, Shimizu T: 3p Interstitial Deletion Including PRICKLE2 in Identical Twins With Autistic Features. Pediatr Neurol, 2014; 51: 730-733.

7) Nakashima M, Miyajima M, Sugano H, Iimura Y, Kato M, Tsurusaki Y, Miyake N, Saitsu H, Arai H, Matsumoto N: The somatic GNAQ mutation c.548G > A (p.R183Q) is consistently found in Sturge-Weber syndrome. J Hum Genet, 2014; 59: 691-693.

8) Shimoji T, Tominaga D, Shimoji K, Miyajima M, Tasato $\mathrm{K}$ : Analysis of pre- and post-operative symptoms of patients with mild trigonocephaly using several developmental and psychological tests. Childs Nerv Syst, 2015; 31: 433-440.

2) Hidenori Oishi (Professor, Division of Neuroendovascular Therapy)

\section{Munetaka Yamamoto (Associate Professor)}

The research in our division encompasses a wide range of topics on cerebrovascular disease and neuroendovascular therapy.

Publications:

1) Oishi H, Yamamoto M, Nonaka S, Shimizu T, Yoshida K, Mitsuhashi T, Arai H: Treatment results of endosaccular coil embolization of asymptomatic unruptured intracranial aneurysms in elderly patients. J Neurointerv Surg, 2014 Jul 17. pii: neurintsurg-2014-011305.

2) Oishi H, Nonaka S, Yamamoto M, Arai H: Feasibility and efficacy of endovascular therapy for ruptured distal anterior cerebral artery aneurysms. Neurol Med Chir (Tokyo), 2013; 53: 304-309.

3) Oishi H, Yamamoto M, Shimizu T, Yoshida K, Arai H: Endovascular therapy of 500 small asymptomatic unrup- 
tured aneurysms. AJNR, 2012; 12: 958-964.

4) Teramoto S, Miyamoto N, Yatomi K, Tanaka Y, Oishi H, Arai H, Hattori N, Urabe T: Exendin-4, a glucagon-like peptide -1 receptor agonist, provides neuroprotection in mice transient focal cerebral ischemia. J Cereb Blood Flow Metab, 2011; 31: 1696-1705.

5) Yoshida K, Melake M, Oishi H, Yamamoto M, Arai H: Transvenous embolization of dural carotid cavernous fistulas: a series of 44 consecutive patients. AJNR, 2010; 31: $651-655$.

\section{3) Atsushi Umemura (Senior Associate Professor, Division of Movement Disorder Unit)}

My group organizes the "Movement Disorder Unit" with neurologists and psychiatrists. The main topic of my research is deep brain stimulation for movement disorders.

\section{Publications:}

1) Oyama G, Shimo Y, Umemura A, Nishikawa N, Nakajima A, Jo T, Nakajima M, Ishii $H$, Arai $H$, Hattori N: Troubleshooting in hospitalized Parkinson's disease patients with a history of deep brain stimulation of the subthalamic nucleus. Neurol Clin Neurosci, 2014; 2: 188192.

2) Umemura A, Oka Y, Yamada K, Oyama G, Shimo Y, Hattori N: Validity of single tract microelectrode recording in subthalamic nucleus stimulation. Neurol Med Chir (Tokyo), 2013; 53: 821-827.

3) Umemura A, Oka Y, Okita K, Matsukawa N, Yamada K: Subthalamic nucleus stimulation for Parkinson disease with severe medication-induced hallucinations or delusions. J Neurosurg, 2011; 114: 1701-1705.

4) Umemura A, Oka Y, Ohkita K, Yamawaki T, Yamada K: Effect of subthalamic deep brain stimulation on postural abnormality in Parkinson disease. J Neurosurg, 2010; 112: 1283-1288.

\section{4) Hidenori Sugano (Associate Professor)}

Madoka Nakajima (Associate Professor)

Atsushi Umemura (Senior associate professor)

My group is devoted to research in functional neurosurgery. We perform clinical studies on epilepsy surgery and deep brain stimulation for movement disorders, among other topics in the field. We also conduct basic research on neurogenesis in the hippocampus by using immuno-histochemistry and patch-clamp technique. Our research topics are neural plasticity related to epileptogenicity and acquiring neural function, and EEG analysis using high-frequency oscillation.

Publications:

1) Nakajima M, Sugano H, Iimura Y, Higo T, Nakanishi H, Shimoji K, Karagiozov KL, Miyajima M, Arai H: Sturge-Weber syndrome with spontaneous intracerebral hemorrhage in childhood. J Neurosurg Pediatr, 2014; 13: 90-93.

2) Sugano H, Nakanishi H, Nakajima M, Higo T, Iimura $Y$, Tanaka K, Hosozawa M, Niijima S, Arai H: Posterior quadrant disconnection surgery for Sturge-Weber syndrome. Epilepsia, 2014; 55: 683-689.

\section{5) Hisato Ishii (Associate Professor)} Yuichi Tange (Assistant Professor)

Our group aims to elucidate the oncogenesis of brain neoplasms and discover specific therapies, especially for hypothalamic and pituitary tumors.

Publications:

1) Tange Y, Miyazaki M, Iwata J, Aiko Y, Sakamoto S, Mori K: Novel antitumor effect of carboplatin delivered by intracerebral microinfusion in a rat malignant glioma model. Neurol Med Chir (Tokyo), 2009; 49: 572-579.

2) Tange $Y$, Kondo A, Egorin MJ, Mania-Farnell B, Daneriallis GM, Nakazaki H, Sredni ST, Rajaram V, Goldman S, Soares MB, Tomita T: Interstitial continuous infusion therapy in a malignant glioma model in rats. Child's Nerv Syst, 2009; 25: 655-662.

\section{6) Akihide Kondo (Associate Professor)}

Our group studies clinical oncology with molecular analysis for tumors and approaches for practical surgeries.

Publications:

1) Kondo A, Goldman S, Lulla RR, Mania-Farnell B, Vanin EF, Sredni ST, Rajaram V, Soares MB, Tomita T: Longitudinal assessment of regional directed delivery in a rodent malignant glioma model. J Neurosurg Pediatr, 2009; 4: 592-598.

\section{7) Takeshi Hara (Assistant Professor)}

Our group aims to treat spinal diseases and to research biomechanics of the cervical spine using 3D models from imaging studies. 